\title{
THE CURRENT STATUS AND FUTURE PERSPECTIVES OF LACTOBIONIC ACID PRODUCTION: A REVIEW
}

\author{
Inga Sarenkova, Inga Ciprovica \\ Latvia University of Life Sciences and Technologies, Latvia \\ inga.sarenkova@inbox.lv
}

\begin{abstract}
Lactobionic acid is a high value added compound industrially produced through energy intensive chemical synthesis, which uses costly metal catalysts, like gold and platinum. In the next years, biotechnological production of lactobionic acid can be supposed to take the full transition to the manufacturing stage. Productivity of lactobionic acid by microbial production can be affected by various factors - choice of microorganism and its concentration, supply of oxygen, temperature, substrate, cultivation method, $\mathrm{pH}$ and aeration rate. The aim was to review research findings for lactobionic acid production as well innovative and efficient technology solutions for self-costs reducing. Whey was recommended as a cheap and suitable substrate for the lactobionic acid production. Whey processing has been advised with Pseudonomas teatrolens in $28^{\circ} \mathrm{C}$ and in $\mathrm{pH} 6$ to 7 for yielding the highest productivity. The increasing commercial importance urges the progression of schemes for lactobionic acid biotechnological manufacturing.
\end{abstract}

Key words: lactobionic acid, lactose, oxidation.

\section{Introduction}

Whey is renewable resource in food industry and contains a lot of milk sugar - lactose. Lactose takes an important role in nutrition. It is a unique disaccharide widespread in the mammalian milk (Gutiérrez, Hamoudi, \& Belkacemi, 2011; Prazeres, Carvalho, \& Rivas, 2012). Application of lactose is limited, because of the intolerance problems of some population segments and due to its low sweetness and low solubility (Gutiérrez, Hamoudi, \& Belkacemi, 2011). In 1990, there was found out that more than $145 \cdot 10^{6}$ ton of whey was produced per year and containing approximately six million tons of lactose (Castillo, 1990). The European Union produced approximately $40 \cdot 10^{6}$ tons per year of whey. Yearly residue of produced whey is approximately $13 \cdot 10^{6}$ tons, which contains approximately 619,250 tons of lactose (El-Tanboly, El-Hofi, \& Khorshid, 2017). Nearly $9 \mathrm{~L}$ of whey is obtained from exactly one kilogram of manufactured cheese; whey is mainly used as animal feed (Onwulata \& Huth 2008). Whey has been used as carbon and nitrogen source in varied biotechnological operations (Prazeres, Carvalho, \& Rivas, 2012).

Lactobionic acid is a disaccharide formed from gluconic acid and galactose, produced by oxidation of lactose. This organic acid is a high value added compound. It is widely applied in medicine, pharmaceutical, food, chemical and in cosmetic industry, due to its excellent properties, like antioxidant, biocompatibility, nontoxicity, chelating, biodegradability and amphiphilic. Lactobionic acid unique properties together with the wide diapason of usage have also created it into a strategic high value added substance for the manufacture of new products (Alonso, Rendueles, \& Diaz, 2013b). This growing commercial significance has conducted the biotechnological production of lactobionic acid as a long lasting production alternative to the expensive and high intensive energy chemical production way (Alonso, Rendueles, \& Diaz, 2011). Pseudomonas taetrolens shows higher ability of conversion per unit of organic matter with no complicated nutrient requirements (Alonso, Rendueles, \& Diaz, 2011), unlike lactobionic acid production from microorganisms such as Burkholderia cepacia or Zymomonas mobilis (Murakami et al., 2003; Malvessi et al., 2013). The aim of this study was to review research findings for lactobionic acid production as well as innovative and efficient technology solutions for shelf costs reducing.

\section{Materials and Methods}

Monographic method has been used for this review. The review summarizes results of lactobionic acid production through a microbiological production pathway and the application of lactobionic acid in food industry. Literature from United States Patents and different scientific journals all around the world has been used in development of the review. It includes information from research conducted in Spain, Canada, United States, Germany, Portugal, Brazil and China.

\section{Results and Discussion \\ Lactobionic acid application in the food industry}

The food industry has great interest or attention to the use of lactobionic acid as a food additive in the last years as calcium carrier, acidifier agent, antioxidant etc. (Table 1). The dairy field has been currently involved in the implementation and development of new production methods inclusive lactobionic acid as one of the main compounds in new dairy gaining technologies (Merrill \& Singh, 2011).

In addition, this compound as a feed additive has been suggested for laying hens, promoting the 
Lactobionic acid applications in food industry

\begin{tabular}{|l|l|}
\hline \multicolumn{1}{|c|}{ Applications } & \multicolumn{1}{c|}{ Reference } \\
\hline Antioxidant & (FDA, 2011) \\
\hline Stabilizer & (FDA, 2011) \\
\hline Gelling agent (in desert products) & (FDA, 2011) \\
\hline Acidifier agent (in fermented milk products) & (Faergemand, Gilleladen, \& Qvist, 2012) \\
\hline Aging inhibitor (for bread) & (Oe \& Kimura, 2011) \\
\hline Water holding capacity agent (in meat products) & (Nielsen, 2009) \\
\hline Flavour enhancer (for foods or beverages) & (Walter \& Begli, 2011) \\
\hline Retarding of lipid oxidation & (Baldwin et al., 2004) \\
\hline Filler (in cheese production) & (Pleissner et al., 2017) \\
\hline Calcium carrier (in food and beverages) & (Pleissner et al., 2017) \\
\hline
\end{tabular}

absorption of calcium and raising the quality of egg shell (Kimura, 2006). Calcium lactobionate has been recently advanced to ensure a valuable access for calcium addition through milk based beverages, non-dairy beverages and cheeses as calcium carriers (Nielsen \& Hoeier, 2009). Functional milk containing lactobionic acid may help to exterminate the deficiency of calcium. Cheese production productivity can boost by adding lactobionic acid indirectly (by putting lactose oxidase) or directly (approximately $10 \%$ of the mixture). This helps reduce processing time and manufacturing costs. Lactobionic acid ensured also sensory properties via lowering of unwanted Maillard reaction products in cooked products (Merrill \& Singh, 2011). An antioxidant mixture containing lactobionic acid has been invented for reducing lipid oxidation in products (Baldwin et al., 2004). Recently for the first time has been reported that lactobionic acid in meat products works as an agent of water holding capacity. Lactobionic acid gives higher industrial yield of meat products due to decreasing of water losses through thawing or cooking processes (Nielsen, 2009).

It does not have a specific colour, flavour or aroma, besides product has primarily antibacterial functions at small doses. Food and Drug Administration (FDA) has already approved the usage of calcium lactobionate as food additive, but the agreement by the European Food Safety Authority (EFSA) is still unsolved, because of the deficiency of the long term influence assessment of lactobionic acid on human health (Gutiérrez, Hamoudi, \& Belkacemi, 2012).

Advantages and disadvantages of lactobionic acid production methods

First time lactobionic acid was discovered via chemical synthesis by Fisher \& Meyer in the year 1889 (Fisher \& Meyer, 1889), after synthesis with bromine. Lactobionic acid is currently produced from lactose in energy intensive way via chemical synthesis for industrial purposes (Kuusisto et al., 2007). The selective conversion of lactose to lactobionic acid consists of the glucose aldehyde group oxidation at the lactose molecule to the carboxylic group (Nakano et al., 2010).

Processes like enzymatic synthesis, biocatalytic oxidation, electrochemical oxidation and heterogeneous catalytic oxidation have been viewed for the lactobionic acid production. Enzymatic synthesis gives higher productivity and lactobionic acid yield than microbial production. Unfortunately, enzymes are quite unstable in production process (Nordkvist, Nielsen, \& Villadsen, 2007). However, the enzymatic synthesis can only be complied with refined lactose (Pleissner et al., 2017). The biocatalytic production of lactobionic acid is based on the oxidation of lactose by using microorganisms as biocatalysts or by specific enzymes. The main reaction mechanism involves the modelling as an intermediate product of lactobionic$\delta$-lactone, which is further hydrolysed to lactobionic acid (Nakano et al., 2010). Through chemical synthesis lactobionic acid can be also produced by lactose oxidation with bromine or by electrocatalytic oxidation with platinum or gold electrodes in alkaline medium (Pleissner et al., 2017). Gutiérrez et al. (Gutiérrez, Hamoudi, \& Belkacemi, 2011) reported that high yield of lactobionic acid (more than 90\%) can be gained via electrocatalytic oxidation. Gold electrodes are the most suitable catalysts for the oxidation of sugars. The main compound of the electrochemical oxidation of lactose is the lactone, which is further hydrolysed to lactobionic acid. First successfully implemented lactobionic acid production example by heterogeneous catalytic oxidation of lactose via palladium and bismuth-palladium catalysts was reached in 1990 (Hendriks, Kuster, \& Marin, 1990).

Nowadays, lactobionic acid is manufactured via chemical synthesis, which is energy intensive and 
very expensive metal catalysts demanding. Attention to biotechnological production increases, because the commercial relevance of lactobionic acid grows fast. The possibility of lactose containing waste or renewable material utilization for lactobionic acid manufacturing farther boosts the interest of the biotechnological course, environmentally and cost effective production (Pleissner et al., 2017).

\section{Lactobionic acid production in microbial synthesis}

It was first reported that some Pseudomonas species are capable to convert lactose to lactobionic acid in 1947. Stodola and Lockwood investigated 15 Pseudomonas species, only Pseudomonas graveolens (today mainly named as teatrolens) showed the capability of lactobionic acid production (Stodola \& Lockwood, 1947). Bioproduction in microbial synthesis from food residue like whey gives an environmentally and sustainably substantiated alternative for lactobionic acid production, unlike it is from chemically synthesis processes. Using whey as cheap source opens a possibility for cost effective lactobionic acid production in microbial synthesis pathway (Alonso, Rendueles, \& Diaz, 2011).

Pseudomonas species produce lactobionic acid through the lactose oxidation pathway (Alonso, Rendueles, \& Diaz, 2012a). Pseudomonas spp. dehydrogenase catalyses lactose oxidation to a lactobiono- $\delta$-lactone using flavin adenine dinucleotide (FAD) as a system of electron transfer. The lactone is hydrolysed by lactonase into lactobionic acid. The procedure is usually managed out at $\mathrm{pH}$ of 6 and at 25 to $50{ }^{\circ} \mathrm{C}$ temperature. At the end of lactose oxidation, the result can be lactobionic acid or its salts. If lactobionate salts are obtained, the mixture is overpassed via purification methods to get pure lactobionic acid (Gutiérrez, Hamoudi, \& Belkacemi, 2011).

Some microorganisms are investigated for their ability to create lactobionic acid. These are Pseudomonas taetrolens (Alonso, Rendueles, \& Diaz, 2011), Pseudomonas aeruginosa (Stodola \& Lockwood, 1947), Acetobacter orientalis (Kiryu et al., 2012), Burkholderia cepacia (Murakami et al., 2003), and Halobacterium saccharovorum (Tomlinson, Strohm, \& Hochstein, 1978). Among above mentioned microorganisms, only Pseudomonas taetrolens has recently been studied for lactobionic acid production at lactose oxidation pathway. Unfortunately, Pseudomonas aeruginosa and Burkholderia cepacia have pathogenicity that makes them unsuitable for the use in food products and delays any further production on industrial scale (Pleissner et al., 2017). Pseudomonas taetrolens is suitable for producing compounds which could be used in food products. It is usually found in spoiled products as natural compounds (West, 2004).
Obtaining lactobionic acid from lactose by using Filamentous fungi, gives only 50\% yield after $120 \mathrm{~h}$ production process, which proposes that it is residual lactose oxidase activity in Filamentous fungi (Pedruzzi, Borges de Silva, \& Rodrigues, 2011; Malvessi et al., 2013) However, the capability of lactose oxidation has been also discovered in red algae, which are able to oxidize various carbohydrates at approximately $\mathrm{pH}$ of 5 (Alonso, Rendueles, \& Diaz, 2011; Murakami et al., 2003). Lactose oxidation by using Acetobacter orientalis gives 97 till 99\% yield using resting cell position in rich nutritive substrate (Kiryu et al., 2012).

As stated of economic feasibility, the productivity of organic acids by microbial production demands to be more than $1 \mathrm{~g} \mathrm{~L}^{-1} \mathrm{~h}^{-1}$ and at the end product concentration needs to be more than $50 \mathrm{~g} \mathrm{~L}^{-1}$ (Yang et al., 2007). The titre obtained through any of biotechnological methods from an industrial point of view must contain at least 50 to $100 \mathrm{~g}$ per $\mathrm{L}$ to reach product concentration which is comparable to the amount obtained in the chemical synthesis (Pollard \& Woodley, 2007). Although the majority of the methods summarized in Table 2 confirms above mentioned criteria, most of these methods could not be performed on a commercial range due to the reason that high production amounts were reached by using resting cell, which are not generally used in the manufacturing (Alonso, Rendueles, \& Diaz, 2017).

The process temperature plays the import role to lactobionic acid production. Providing the process temperature at $28{ }^{\circ} \mathrm{C}$ was able to reach higher cell density and at the same time promoted lactose conversion process to lactobionic acid. The high yield up to $98 \%$ and the specific productivity $\left(1.73 \mathrm{~g} \mathrm{~g}^{-1}\right.$ per h) was reached in lactobionic acid production from whey and results confirmed the significance of this strategy for lactose bioconversion by Pseudomonas taetrolens in dairy industry (Alonso, Rendueles, \& Diaz, 2017). The effect of different whey concentrations was also explored, recording that the production of lactobionic acid increased with increasing of whey concentration (Miyamoto, Ooi, \& Kinoshita, 2000).

The adverse effect of an over-supply of oxygen and the operational $\mathrm{pH}$, has been identified as the main bioprocessing factor, affecting bioproduction. The usage of large aeration rate was disadvantageous production of lactobionic acid although the cell growth was accelerated by increasing the rate of aeration (Alonso, Rendueles, \& Diaz, 2012a). Also, biomass concentration affects productivity of lactobionic acid, if at the beginning the biomass concentration is higher, the productivity of lactobionic acid is higher, too. Pseudomonas taetrolens showed the reduced cellular distribution at $\mathrm{pH}$ less than 6 and a further delay of the lactobionic acid production. By $\mathrm{pH}$ values over 7 Pseudomonas taetrolens behaviour and 


\section{Summary of research results on the microbial synthesis of lactobionic acid}

Table 2

\begin{tabular}{|c|c|c|c|c|c|c|c|c|}
\hline Microorganisms & Method & Substrate & 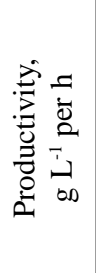 & 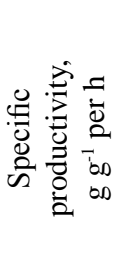 & 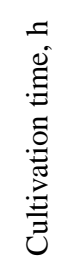 & 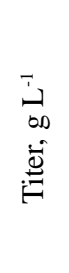 & 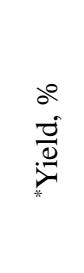 & References \\
\hline $\begin{array}{l}\text { Pseudomonas } \\
\text { graveolens }\end{array}$ & $\begin{array}{c}B \text { in rotating } \\
\text { drums }\end{array}$ & lactose & - & - & 165 & - & 75 & $\begin{array}{c}\text { Stodola \& Lockwood, } \\
1947\end{array}$ \\
\hline $\begin{array}{l}\text { Burkholderia } \\
\text { cepacia }\end{array}$ & $\begin{array}{l}\text { FB in } \\
\text { bioreactor }\end{array}$ & $\begin{array}{l}\text { lactose, glucose, } \\
\text { yeast extract, salts, } \\
\text { peptone }\end{array}$ & 3.56 & - & 50 & 178 & 85 & $\begin{array}{c}\text { Meiberg, } \\
\text { Bruinenberg, \& } \\
\text { Sloots, } 1990\end{array}$ \\
\hline $\begin{array}{l}\text { Pseudomonas sp. } \\
\text { LS131 }\end{array}$ & $\begin{array}{c}\text { FB in } \\
\text { bioreactor }\end{array}$ & $\begin{array}{l}\text { lactose, peptone, } \\
\text { salts }\end{array}$ & 1.87 & - & 155 & 290 & 90 & $\begin{array}{l}\text { Miyamoto, Ooi, \& } \\
\text { Kinoshita, } 2000\end{array}$ \\
\hline $\begin{array}{l}\text { Burkholderia } \\
\text { cepacia no. } 24\end{array}$ & $\begin{array}{l}\text { FB in shake- } \\
\text { flask }\end{array}$ & $\begin{array}{l}\text { lactose, peptone, } \\
\text { salts, yeast extract }\end{array}$ & 1.67 & - & 240 & 400 & 100 & $\begin{array}{l}\text { Murakami et al., } \\
2003\end{array}$ \\
\hline $\begin{array}{l}\text { Burkholderia } \\
\text { cepacia no. } 24\end{array}$ & $\begin{array}{l}\text { B in shake- } \\
\text { flask }\end{array}$ & $\begin{array}{l}\text { lactose, yeast } \\
\text { extract, salts, corn } \\
\text { steep liquor }\end{array}$ & 5.55 & - & 27 & 150 & $\sim 100$ & $\begin{array}{l}\text { Murakami et al., } \\
2006\end{array}$ \\
\hline $\begin{array}{l}\text { Zymomonas } \\
\text { mobilis }\end{array}$ & $\begin{array}{c}\mathrm{B} \text { in } \\
\text { bioreactor }\end{array}$ & lactose & 5.80 & 0.80 & 22 & 125 & 100 & $\begin{array}{c}\text { Pedruzzi, Borges de } \\
\text { Silva, \& Rodrigues, } \\
2011\end{array}$ \\
\hline $\begin{array}{l}\text { Pseudomonas } \\
\text { taetrolens }\end{array}$ & $\begin{array}{c}\mathrm{B} \text { in } \\
\text { bioreactor }\end{array}$ & whey & 0.70 & 0.56 & 58 & 42 & 100 & $\begin{array}{c}\text { Alonso, Rendueles, \& } \\
\text { Diaz, } 2011\end{array}$ \\
\hline $\begin{array}{l}\text { Acetobacter } \\
\text { orientalis }\end{array}$ & $\begin{array}{c}\text { B in } \\
\text { bioreactor }\end{array}$ & $\begin{array}{l}\text { Lactose, } \\
\text { yeast extract, } \\
\text { polypeptone, } \\
\text { Dglucose, salts. }\end{array}$ & 0.54 & - & 72 & 49 & 98 & Kiryu et al., 2012 \\
\hline $\begin{array}{l}\text { Pseudomonas } \\
\text { taetrolens }\end{array}$ & $\begin{array}{c}\mathrm{B} \text { in } \\
\text { bioreactor }\end{array}$ & whey & 1.27 & 0.94 & 30 & 42 & 100 & $\begin{array}{c}\text { Alonso, Rendueles, \& } \\
\text { Diaz, 2012a }\end{array}$ \\
\hline $\begin{array}{l}\text { Pseudomonas } \\
\text { taetrolens }\end{array}$ & $\begin{array}{l}\text { B in shake- } \\
\text { flask }\end{array}$ & whey & 0.70 & 0.42 & 60 & 42 & 100 & $\begin{array}{c}\text { Alonso, Rendueles, \& } \\
\text { Diaz, 2012b }\end{array}$ \\
\hline $\begin{array}{l}\text { Zymomonas } \\
\text { mobilis }\end{array}$ & $\begin{array}{c}\text { B in } \\
\text { bioreactor }\end{array}$ & lactose, fructose & 7.60 & 0.30 & 24 & 182 & 78 & Malvessi et al., 2013 \\
\hline $\begin{array}{l}\text { Pseudomonas } \\
\text { taetrolens }\end{array}$ & $\begin{array}{c}\text { B in } \\
\text { bioreactor }\end{array}$ & concentrated whey & 1.63 & 1.02 & 48 & 78 & 100 & $\begin{array}{c}\text { Alonso, Rendueles, \& } \\
\text { Diaz, 2013a }\end{array}$ \\
\hline $\begin{array}{l}\text { Pseudomonas } \\
\text { taetrolens }\end{array}$ & $\begin{array}{l}\text { FB in } \\
\text { bioreactor }\end{array}$ & concentrated whey & 2.05 & 1.40 & 80 & 164 & 82 & $\begin{array}{c}\text { Alonso, Rendueles, \& } \\
\text { Diaz, 2013a }\end{array}$ \\
\hline $\begin{array}{l}\text { Pseudomonas } \\
\text { taetrolens }\end{array}$ & $\begin{array}{l}\text { FB in } \\
\text { bioreactor }\end{array}$ & whey + glucose & 1.28 & 2.15 & 48 & 78 & 98 & $\begin{array}{c}\text { Alonso, Rendueles, \& } \\
\text { Diaz, } 2015\end{array}$ \\
\hline $\begin{array}{l}\text { Pseudomonas } \\
\text { taetrolens }\end{array}$ & $\begin{array}{l}\text { FB in } \\
\text { bioreactor }\end{array}$ & whey + glycerol & 0.93 & 1.65 & 48 & 65 & 82 & $\begin{array}{c}\text { Alonso, Rendueles, \& } \\
\text { Diaz, } 2015\end{array}$ \\
\hline $\begin{array}{l}\text { Pseudomonas } \\
\text { taetrolens }\end{array}$ & $\begin{array}{l}\text { FB in } \\
\text { bioreactor }\end{array}$ & whey+ lactose & 1.40 & 2.05 & 48 & 100 & 100 & $\begin{array}{c}\text { Alonso, Rendueles, \& } \\
\text { Diaz, } 2015\end{array}$ \\
\hline $\begin{array}{l}\text { Pseudomonas } \\
\text { taetrolens }\end{array}$ & $\begin{array}{c}\text { B in } \\
\text { bioreactor }\end{array}$ & whey & 2.04 & 1.73 & 24 & 49 & 98 & $\begin{array}{c}\text { Alonso, Rendueles, \& } \\
\text { Diaz, } 2017\end{array}$ \\
\hline
\end{tabular}

'-'- Not accessible;

B- Batch;

FB- Fed-batch;

*- Yield was set as the percentage of lactose oxidized to lactobionic acid after end of process. 
production process were also negatively influenced (Alonso, Rendueles, \& Diaz, 2013a). Alonso et al. (Alonso, Rendueles, \& Diaz, 2012a) also observed that production of lactobionic acid was negatively affected by large aeration and agitation rate.

Microbial production methods for production of lactobionic acid are in turn related with complicated and expensive purification processing stages in comparison to enzymatic methods. From the industrial point of view, microbial methods show strong challenges, which may delay the process progression schedule (Alonso, Rendueles, \& Diaz, 2017).

\section{Purification methods}

The first try to purify lactobionic acid in the end of microbial production was a reactive extraction method with ethanol (Lockwood \& Stodola, 1947). Recovery process depends primarily on the form of the matrix occupied for obtaining lactobionic acid, metabolites and composition of media.

Lactobionic acid recovery after biobased production could be completed by accepted techniques including extraction, adsorption or precipitation using ion-exchange resins (Pedruzzi, Borges de Silva, \& Rodrigues, 2008). By passing the substrate of lactobionate ions through a series of ion exchange resins, a batch of pure lactobionic acid can be produced with insignificant amounts of calcium ions. Other technologies like ethanol precipitation (Armarego \& Chai, 2009), electrodialysis (Perettia, Silveiraa, \& Zeni, 2009), evaporation and crystallization are also suitable for the lactobionic acid recovery (Jones, Vestal, \& Chi, 2002). Between all the techniques of purification that have been studied, ion-exchange purification of lactobionic acid has been selected as the advantaged purification method (Alonso, Rendueles, \& Diaz, 2013b).

\section{Conclusions}

This study has showed the preference of whey as a cheap substance for biobased production of lactobionic acid by Pseudomonas taetrolens on an industrial scale. The high level titre was obtained with a high lactobionic acid yield through microbiological synthesis.

Production of lactobionic acid through microbial synthesis may overcome the major lack, such as complicated and time wasted upstream stages. Lactobionic acid purification after cultivation stage will certainly be the target of intense future research. Overall, combined cultivation and purification processes may improve productivity and produce a pure product, thereby further making purification process easier.

\section{References}

1. Alonso, S., Rendueles, M., \& Diaz, M. (2011). Efficient lactobionic acid production from whey by Pseudomonas taetrolens under pH-shift conditions. Bioresour. Technol. 102, 9730-9736. DOI: 10.1016/j. biortech.2011.07.089.

2. Alonso, S., Rendueles, M., \& Diaz, M. (2012a). Role of dissolved oxygen availability on lactobionic acid production from whey by Pseudomonas taetrolens. Bioresour. Technol. 109, 140-147. DOI: 10.1016/j. biortech.2012.01.045.

3. Alonso, S., Rendueles, M., \& Diaz, M. (2012b). Physiological heterogeneity of Pseudomonas taetrolens during lactobionic acid production. Appl. Microbiol. Biotechnol. 96, 1465-1477. DOI: 10.1007/s00253012-4254-2.

4. Alonso, S., Rendueles, M., \& Diaz, M. (2013a). Feeding strategies for enhanced lactobionic acid production from whey by Pseudomonas taetrolens. Bioresour. Technol. 134, 134-142. DOI: 10.1016/j. biortech.2013.01.145.

5. Alonso, S., Rendueles, M., \& Diaz, M.(2013b). Bio-production oflactobionic acid: current status, applications and future prospects. Biotechnol. Adv. 31(8), 1275-1291. DOI: 10.1016/j. biotechadv.2013.04.010196.

6. Alonso, S., Rendueles, M., \& Diaz, M. (2015). Simultaneous production of lactobionic and gluconic acid in cheese whey/glucose co-fermentation by Pseudomonas taetrolens. Bioresour. Technol. 196, 314-323. DOI: 10.1016/j.biortech.2015.07.092.

7. Alonso, S., Rendueles, M., \& Diaz, M. (2017). Tunable decoupled overproduction of lactobionic acid in Pseudomonas taetrolens through temperature-control strategies. Process Biochemistry. 58, 9-16. DOI: 10.1016/j.procbio.2017.04.034.

8. Armarego, W.L., \& Chai, C.L. (2009). Purification of biochemicals and related products. In W.L. Armarego \& C.L. Chai (Eds.), Purification of laboratory chemicals. (6th ed.). Oxford: Elsevier Inc.

9. Baldwin, C., Akashe, A., Dinwoodie, R., Koka, R., West, L.G., \& Kortum, O. (2004). U.S. Patent No. 0170728. United States Patent. Kraft Foods Group Brands LLC.

10. Castillo, F.J. (1990). Lactose metabolism by yeasts. In H. Verachtert \& R. De Mot (Eds.), Yeast biotechnology and biocatalysis. (pp. 297-320). New York: Marcel Dekker. 
11. El-Tanboly, E.S., El-Hofi, M., \& Khorshid. (2017). Recovery of Cheese Whey, a by-Product from the Dairy Industry for use as an Animal Feed. J. Nutr. Health. Food. Eng. 6(5), 1-7. DOI: 10.15406/ jnhfe.2017.06.00215.

12. Faergemand, M., Gilleladen, C., \& Qvist, K.B. (2012). U.S. Patent No. US0045546. United States Patent. Chr Hansen AS, Novozymes AS.

13. FDA. Code of Federal Regulations, Title 21, 21 CFR 172.720. US Food and Drug Administration. (2011). Retrieved February 28, 2018, from: http://www.accessdata.fda.gov/scripts/cdrh/cfdocs/cfCFR.

14. Fisher, E., \& Meyer, J. (1889) Oxydation des milchzuckers (Oxidation of the milk sugar). Ber. Dtsch. Chem. Ges. 22, 361-364. DOI: 10.1002/cber.18890220182.

15. Gutiérrez, L.F., Hamoudi, S., \& Belkacemi, K. (2011). Selective production of lactobionic acid by aerobic oxidation of lactose over gold crystallites supported on mesoporous silica. Applied Catalysis A: General, 402, 94-103. DOI: 10.1016/j.apcata.2011.05.034.

16. Gutiérrez, L.F., Hamoudi, S., \& Belkacemi, K. (2012). Lactobionic acid: a high value-added lactose derivative for food and pharmaceutical applications. Int. Dairy J. 26(2), 103-111. DOI:10.1016/ j.idairyj.2012.05.003.

17. Hendriks, H.E.J., Kuster, B.F.M., \& Marin, G.B. (1990). The effect of bismuth on the selective oxidation of lactose on supported palladium catalysts. Carbohydrate Research. 204, 121-129. DOI: 10.1016/00086215(90)84027-R.

18. Jones, W.E., Vestal, N.Y., \& Chi, Y.H. (2002). U.S. Patent No. US0006884. United States Patent. BioLife Solutions Inc.

19. Kimura, T. (2006). U.S. Patent No. US0022463. United States. Daicel Corp.

20. Kiryu, T., Yamauchi, K., Masuyama, A., Ooe, K., Kimura, T., Kiso, ... Murakami, H. (2012). Optimization of lactobionic acid production by Acetobacter orientalis isolated from Caucasian fermented milk, 'Caspian Sea Yogurt'. Biosci. Biotech. Bioch. 76(2), 361-363. DOI: 10.1271/bbb.110608.

21. Kuusisto, J., Tokarev, A.V., Murzina, E.V., Roslund, M.U., Mikkola, J.P., \& Murzin, D.Y. (2007). From renewable raw materials to high value-added fine chemicals-catalytic hydrogenation and oxidation of D-lactose. Catal. Today. 121, 92-99. DOI: 10.1016/j.cattod.2006.11.020..

22. Malvessi, E., Carra, S., Pasquali, F.C., Kern, D.B., da Silveira, M.M., \& Ayub, M.A.Z. (2013). Production of organic acids by periplasmic enzymes present in free and immobilized cells of Zymomonas mobilis. $J$. Ind. Microbiol. Biotechnol. 40, 1-10. DOI: 10.1007/s10295-012-1198-6.

23. Meiberg, J.B.M., Bruinenberg, P.M., \& Sloots, B. (1990). U.S. Patent No. US5043275. United States Patent. Cooperatie Avebe UA.

24. Merrill, R.K., \& Singh, M. (2011). U.S. Patent No. US8021704. United States Patent. Leprino Foods Co.

25. Miyamoto, Y., Ooi, T., \& Kinoshita, S. (2000). Production of lactobionic acid from whey by Pseudomonas sp. LS13-1. Biotechnol. Lett. 22(5), 427-430. DOI:10.1023/a:1005617903152.

26. Murakami, H., Seko, A., Azumi, M., Kiso, T., Kiryu, T., Kitahata, S. (2006). Microbial conversion of lactose to lactobionic acid by resting cells of Burkholderia cepacia No. 24. J. Appl. Glycosci. 53, 7-11. DOI: $10.5458 /$ jag.53.7.

27. Murakami, H., Seko, A., Azumi, M., Ueshima, N., Yoshizumi, H., Nakano, H., \& Kitahata, S. (2003). Fermentative production of lactobionic acid by Burkholderia cepacia. J. Applied Glycosci. 50, 117-120. DOI: $10.5458 /$ jag.50.117.

28. Nakano, H., Kiryu, T., Kiso, T., \& Murakami, H. (2010). Biocatalytic production of lactobionic acid. In C.T. Hou \& J.F. Shaw (Eds). Biocatalysis and biomolecular engineering. New Jersey: John Wiley \& Sons Inc.

29. Nielsen, P.M., \& Hoeier, E. (2009). World Intellectual Property Organization. Patent No. WO2009007398A1. United States Patent. Chr. Hansen AS.

30. Nielsen, P.M. (2009). U.S. Patent No. US0214752. United States Patent. Novozymes AS.

31. Nordkvist, M., Nielsen, P.M., \& Villadsen, J. (2007). Oxidation of lactose to lactobionic acid by a Microdochium nivale carbohydrate oxidase: kinetics and operational stability. Biotechnol. Bioeng. 97, 694-707. DOI: 10.1002/bit.21273.

32. Oe, K., \& Kimura, T. (2011). Japanese Patent No. 2011177121. Japan. Unitika LTD.

33. Onwulata, C.I., \& Huth, P.J. (2008). Whey processing, functionality and health benefits. USA: Wiley Blackwell, IFT Press.

34. Pedruzzi, I., Borges da Silva, E.A., \& Rodrigues, A.E. (2008). Selection of resins, equilibrium and sorption kinetics of lactobionic acid, fructose, lactose and sorbitol. Purif. Technol. 63, 600-611. DOI: 10.1016/j. seppur.2008.07.001. 
35. Pedruzzi, I., Borges da Silva, E.A., \& Rodrigues, A.E. (2011). Production of lactobionic acid and sorbitol from lactose/fructose substrate using GFOR/GL enzymes from Zymomonas mobilis cells: a kinetic study. Enzyme. Microb. Technol. 49, 183-91. DOI: 10.1016/j.enzmictec.2011.04.017.

36. Perettia, F.A., Silveiraa, M.M., \& Zeni, M. (2009). Use of electrodialysis technique for the separation of lactobionic acid produced by Zymomonas mobilis. Desalination. 245, 626-630. DOI: 10.1016/j. desal.2009.02.029.

37. Pleissner, D., Dietz, D., Henri van Duuren, J.B.J., Wittmann, C., Yang, X., Lin, C.S.K., \& Venus, J. (2017). Biotechnological Production of Organic Acids from Renewable Resources. Advances in Biochemical Engineering/Biotechnology. 1-38. DOI: 10.1007/10_2016_73.

38. Pollard, D.J., \& Woodley, J.M. (2007). Biocatalysis for pharmaceutical intermediates: the future is now. Trends. Biotechnol. 25, 66-73. DOI: 10.1016/j.tibtech.2006.12.005.

39. Prazeres, A.R., Carvalho, F., \& Rivas, J. (2012). Cheese whey management: a review. J. Environ. Manag. 110,48-68. DOI: 10.1016/j.jenvman.2012.05.018.

40. Stodola, F.H., \& Lockwood, B.L. (1947). The oxidation of lactose and maltose to bionic acids by Pseudomonas. J. Biol. Chem. 171, 213-221.

41. Tomlinson, G.A., Strohm, M.P., \& Hochstein, L.I. (1978). Metabolism of carbohydrates by extremely halophilic bacteria-identification of lactobionic acid as a product of lactose metabolism by Halobacterium saccharovorum. Can. J. Microbiol. 24(8), 898-903. DOI: 10.1139/m78-150.

42. Walter, T., \& Begli, H.A. (2011). U.S. Patent No. US20110244080. United States Patent. Südzucker Aktiengesellschaft Mannheim/Ochsenfurt.

43. West, T.P. (2004). Regulation of pyrimidine nucleotide formation in Pseudomonas taetrolens ATCC 4683. Microbiol. Res. 159, 29-33. DOI: 10.1016/j.micres.2004.01.007.

44. Yang, S.T., Huang, H., Tay, A., Qin, W., De Guzman, L., \& San Nicolas, E.C. (2007). Extractive fermentation for the fermentation of carboxylic acids. In S.T. Yang (Ed), Bioprocessing for value-added products from renewable resources. (pp. 421-446). Oxford: Elsevier Inc. 